\title{
ANTIHELMINTIC EFFECT OF EMBELIA TSJERIAM-COTTAM
}

\section{Manjusha Suresh Nikam¹, Md. Rageeb Md. Usman", Gautam P. Vadnere ${ }^{1}$}

${ }^{* 1}$ Department of Pharmacognosy, Smt. Sharadchandrika Suresh Patil College of Pharmacy, Chopda, Maharashtra, India

\section{ABSTRACT}

The present study was undertaken to investigate the anthelmintic activity of extract of Embeliatsjeriam-cottam using earthworm. Different concentrations of standard drug (Albendazole) and extract of Embeliatsjeriam-cottam fruits were employed and the average time required for paralysis and death was noted. It was found that the Paralysis time \& Death time was lowest for $5 \%$ concentration of Ethanolic extract and Death time was slightly better than Albendazole Standard solution. Though Ethanolic Extract can be compared to the Standard hence establishing the pharmacological antihelminthic activity of Embelia tsjeriamcottam.

Keywords:Embelia tsjeriam-cottam Anthelmintic Activity, Albendazole, Ethanolic Extract.

\section{INTRODUCTION}

Helminthes infections are among the most widespread infections in humans, distressing a huge population of the world. The human roundworm A. lumbricoides is one of the most common parasites in the world, infecting 1.2 billion people globally. Infections are most commonly documented in Asia, sub-Saharan Africa, the Americas and China. The spectrum of disease associated with A. lumbricoides infection is known as ascariasis, and morbidity assessed as disability adjusted life years (DALYs) is approximately 10.5 million. Furthe rmore, morbidity with serious health consequences is observed in 122 million cases per year $[1,2]$ The World Health Organization reports that 35\% diseases are because of roundworm, which is a typical parasitic worm. More than 1.5 billion individuals or $24 \%$ of the total population are tainted with soil-transmitted (STH) helminth contaminations around the world. [3] However, ascariasis is still considered a neglected tropical disease (NTD).

The community-based control of STHs is based on mass drug administration by two synthetic anthelmintics, albendazole and mebendazole. [4] A wide spread resistance to the commercially available anthelmintic treatments has been observed in multiple nematode species. [5] Therefore, alternative anthelmintic strategies are urgently needed. In addition anthelmintic strategies such as grazing management, biological control with nematophagous fungi or food supplementation with leguminous plants accumulating high amounts of condensed tannins, phytotherapy could be a part of an integrated control system. The family 
Myrsinaceae consists of nearly1000 species of trees and shrubs spread over 33 genera including four genera namely Myrsine, Maesa, Rapanea and Embelia, which are widely used in herbal medicines. Embelia tsjeriam-cottam is a large scandent shrub, distributed throughout India and belongs to the family Myrsinaceae. It is commonly known as Baberang in Hindi and Vidangain Sanskrit.The dried fruits are being used for the preparation of medicine. [6] Embelia species identified by Susruta (Father of surgery) as anthelmintic, alternative and tonic. [7] Further Dr Harris found in ancient Arabian writing as birang-Ikabauli for remedy of tapeworm. Embelin has been isolated and quantified in Embelia tsjeriam-cottam Burm. f. and other species of Myrsinaceae family. Embelin such evaluated against Heligmosomoide spolygyrus in mice significantly reduced the total worm counts.In the present study, the anthelmintic potential of traditionally used medicinal plant Embelia tsjeriam-cottam was scientifically explored against Earth worm model to substantiate the folklore claims.

\section{MATERIALS AND METHODOLOGY}

\section{Plant Collection and Authentification}

E. tsjeriam fruits and seeds were collected with the help of manual like clippers, diggers, scrapers, etc by the lab technicians from Department of Pharmacognosy, College of Pharmacy, Chopda (Jalgaon, Maharashtra) and Herbarium sheets were prepared. The student collected the requisite from the department. Further, Botanical Survey of India, Pune, authenticated the plant and its constituents. E.tsjeriam-cottam were taxonomically identified and authenticated by (Dr. C R. Jadhav, Botanist) at Botanical Survey of India, Pune, Maharashtra.

\section{Experimental Animal}

For the experiment, earthworms were collected from moist soil from local Earthworm Project and washed with normal saline to remove soil and fecal matter during the experiment. The earthworms of $5-7 \mathrm{~cm}$ length and $0.2-0.3 \mathrm{~cm}$ width were used for the experimental protocol.

\section{METHODOLOGY FOR THE STUDY}

\section{Extraction of Active Constituents from Embilia Tsjeriam-CottamFruits [8-12]}

1. Collected plant parts were air dried under shade and then ground to a coarse powder using a grinder. Finely powdered Embelia tsjeriam-cottam fruit-samples were extracted using Soxhlet method. 
2. Powdered sample (100g) was extracted through Soxhlet apparatus for16-18hrs with acetone, ethanol and methanol solvent systems separately. The total extract was condensed in dry bath and kept as embelin sample stock solution.

\section{Standardization of Plant Extract and Its Bioactive Fractions Embelin by Using}

\section{Phytochemical and Analytical Methods}

\section{FTIR $[13,14]$}

Fixed amount of plant specimen was mixed with $\mathrm{KBr}$ salt, using a mortar and pestle, and compress edintoathin pellet. Infra red spectra were recorded as $\mathrm{KBr}$ pellets on a Thermo scientific Nicot iS5 iD1 transmission, between 4000-400 cm-1 21. The powdered sample of the plant extract was treated for FT-IR spectroscopy. The result was analyzed based on peak obtained.

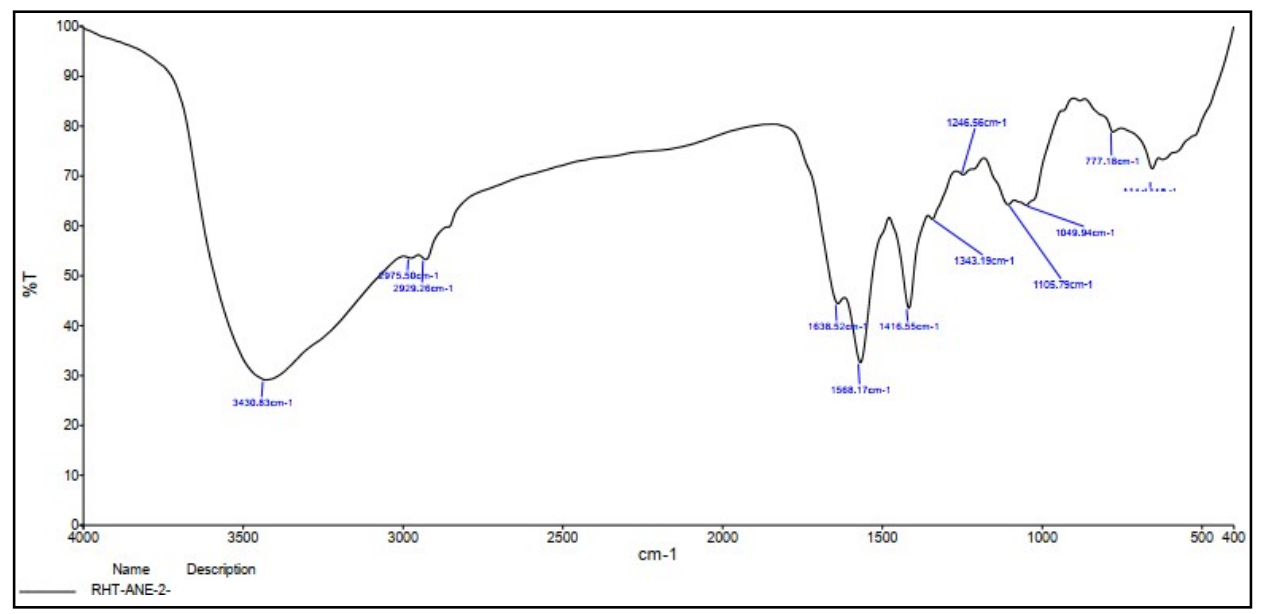

Figure 1: FTIR of E.tsjeriam

Table 1: FTIR of E.tsjeriam peaks interpretation

\begin{tabular}{|c|l|l|l|}
\hline Frequency (cm-1) & Type of Vibration & Functional Group & Intensity \\
\hline 3480.83 & O-H stretch, H-bonded & Alcohol & Strong, broad \\
\hline 2975.50 & C-H stretch & Alkane & Strong \\
\hline 2929.26 & C-H stretch & Alkane & Strong \\
\hline 1638.52 & C=C stretch & Aromatic & Medium-weak \\
\hline 1568.17 & N-H bending & Amide & Strong \\
\hline 1416.55 & C-C stretch & Aromatic & Medium \\
\hline 1343.19 & N-O symmetric stretch & Nitro compounds & Medium \\
\hline 1246.56 & C-O stretch & Alcohol, & Strong \\
\hline 1105.75 & C-O stretch & Alcohol, & Strong \\
\hline
\end{tabular}


The leaf powder of E. tsjeriam-cottam exhibited 12 characteristic bands.The highest band occurred at $3480.83 \mathrm{~cm}-1$ indicating the presence of functional groups like alcohols and phenols having $\mathrm{O}-\mathrm{H}$ stretch and $\mathrm{H}-$ bonded groups, $2975.50 \mathrm{~cm}-1$ indicating the presence of alkenes (C-Hstretch) group, $1638.52 \mathrm{~cm}-1$ indicating the presence of aromatic $(\mathrm{C}=\mathrm{C}$ strech), $1416.55 \mathrm{~cm}-1$ indicating the presence of amide ( $\mathrm{N}-\mathrm{H}$ bending), $1343.19 \mathrm{~cm}-1$ indicating the presence of nitro compounds (N-O symmetric stretch), $1049.94 \mathrm{~cm}-$ 1indicating the presence of aliphatic amine (C-N Stretch).

\section{TLC[15]}

Crude embelin extract (10 $\mu \mathrm{l}$ each) solution was used for the chromatographic method to identify and isolate the pure embelin. The mobile phase selected for use was n-Propanol: $\mathrm{n}$ - Butanol: Ammonia in a ratio of 7:1:2 Spots were detected by using 1\% solution of vanillin in methanolic sulfuric acid as chromatogenic reagents and viewed under ultraviolet light at 365nm wavelength or identification of the separated compounds.

The Rf value of sample was determined to ensure presence of embelin in the extracted sample against the standard. The Rf values were found to be Standard which established the efficacy of the Extraction processs.

\section{In Vitro Pharmacological Evaluation Of EmbiliaTsjeriam-Cottam Extract For Its} Antihelminthic Activity For Treatment Of Ascaris (Intestinal Ring Worm) By Using Earthworms As Culture [16,17,18]

Pheretima posthuma were used because of its anatomical and physiological similarity with intestinal roundworm parasites of human beings and them for the fact that they belong to same group of Annelids. All the test solutions and standard drug solutions were prepared freshly before starting the experiment. Albendazole $(10 \mathrm{mg} / \mathrm{ml})$ was used as reference standard while saline water served as a control.20 worms were used to carry out the experiment. $100 \mathrm{ml}$ formulations containing concentrations of acetone, methanol \& ethanol extracts of were used. The time for paralysis (in min) was noted when no movement of any sort could be observed except when the worms were shaken vigorously. The time of death of the worms (in min) was recorded after ascertaining that worms neither moved when shaken vigorously or when dipped in warm water $\left(50^{\circ} \mathrm{C}\right)$. 


\section{RESULTS}

The results of anthelmintic activity of different concentrations of Standard drug and extract of Embiliatsjeriam- cottam fruits are depictedinTable2.

Table2: In-VitroPharmacological Activity Results

\begin{tabular}{|l|c|c|c|}
\cline { 3 - 4 } Extracts Used & Concentration of Extracts used (\%) & Time (sec) & \multirow{2}{*}{ Death } \\
\hline \multirow{3}{*}{ Acetone } & 1 & Paralysis & \\
\cline { 2 - 4 } & 2.5 & 200 & 280 \\
\cline { 2 - 4 } & 5 & 180 & 240 \\
\hline \multirow{3}{*}{ Methanol } & 1 & 350 & 420 \\
\cline { 2 - 4 } & 2.5 & 290 & 350 \\
\hline \multirow{3}{*}{ Ethanol } & 5 & 210 & 190 \\
\cline { 2 - 4 } & 1 & 180 & 300 \\
\cline { 2 - 4 } & 2.5 & 340 & 450 \\
\hline \multirow{3}{*}{$\begin{array}{l}\text { Albendazole } \\
\text { Standard }\end{array}$} & 5 & 200 & 300 \\
\cline { 2 - 5 } & 2.5 & 90 & 150 \\
\hline
\end{tabular}

The results revealed concentration dependent activity. The average paralysis time (in sec) in different concentrations of Standard drug was found to be 340, 200 and 90while the average death time (in sec) was found to be 450, 300 and 150. Ethanol extract of Embelia tsjeriamcottam, in $1 \%, 2.5 \%$ and $5 \%$ was found to cause paralysis of worms in 240, 180 and 100 seconds respectively.

It was found that the Paralysis time \& Death time was lowest for 5\% concentration of Ethanolic extract and Death time was slightly better than Albendazole Standard solution. Though Ethanolic Extract can be compared to the Standard hence establishing the pharmacological antihelminthic activity of Embeliatsjeriam-cottam.

\section{CONCLUSION}

Albendazole $(10 \mathrm{mg} / \mathrm{ml})$ was used as reference standard while saline water served as a control. 20 worms were used to carry out the experiment.100 $\mathrm{ml}$ formulations containing concentrations of acetone, methanol \&ethanol extracts of Embiliatsjeriam- cottamfruits 
were used. The time for paralysis (in min) was noted when no movement of any sort could be observed except when the worms were shaken vigorously. The time of death of the worms (in min) was recorded after ascertaining that worms neither moved when shaken vigorously or when dipped in warm water $\left(50^{\circ} \mathrm{C}\right)$. It was found that the Paralysis time \& Death time was lowest for 5\% concentration of Ethanolic extract and Death time was slightly better than Albendazole Standard solution. Though Ethanolic Extract can be compared to the Standard hence establishing the pharmacological antihelminthic activity of Embeliatsjeriam-cottam.

\section{CONFLICT OF INTEREST}

Authors have no conflicts of interest to declare.

\section{ACKNOWLEDGEMENTS}

The authors are thankful to the Management and Principal, Smt. Sharadchandrika Suresh Patil College of Pharmacy, Chopda, Maharashtra, India for providing necessary facilities for research work.

\section{REFERENCES}

1. Dold C, Holland CV. Ascaris and ascariasis. Microbes and infection. 2011 Jul1;13(7):6327.

2. De Silva NR, Brooker S, Hotez PJ, Montresor A, Engels D, Savioli L. Soil-transmitted helminth infections: updating the global picture. Trends in parasitology. 2003 Dec 1;19(12):547-51.

3. (2016) World Health Organization (WHO). Soil-transmitted helminthinfections. Fact sheet.www.who.int.

4. Dunn JC, Turner HC, Tun S, Anderson RM. Epidemiological surveys of, and research on, soil-transmitted helminths in Southeast Asia: a systematic review. Parasit Vectors. 2016;9:31.

5. R.P.Choudhury, A.M.Ibrahim, H.N.Bharathi, P.Venkatasubramanian; Electronic Journal of Food and Plant Chemistry, 2(1), 20-24 (2007).

6. .http://www.ccrhindia.org/abstracts/cv/embelia.htm

7. The Ayurvedic Pharmacopoeia of India. Government of India, Ministry of Health \& Family Welfare, Department of Aysuh 2001; 1(1):163-165.

8. Mohaptra M, Basak UC. Assessment of embelin in fruits of Embeliatsjeriam-cottam A. 
DC., a threatened medicinal plant of Odisha, India. American Journal of PharmTech Research. 2014;4:212.

9. Kaufmann B, Christen P. Recent extraction techniques for natural products: microwave-assisted extraction and pressurised solvent extraction. Phytochemical Analysis: An International Journal of Plant Chemical and Biochemical Techniques. 2002 Mar;13(2):105-13.

10. Mukherjee PK, Maity N, Nema NK, Sarkar BK. Bioactive compounds from natural resources against skin aging. Phytomedicine. 2011 Dec 15;19(1):64-73.

11. Handa SS, Khanuja SP, Longo G, Rakesh DD ,United Nations Industrial Development Organization,Extraction technologies for medicinal and aromatic plants. Earth, Environmental and Marine Sciences and Technologies; 2008.

12. Naude Y, De Beer WH, Jooste S, Van Der Merwe L, Van Rensburg SJ. Comparison of supercritical fluid extraction and Soxhlet extraction for the determination of DDT, DDD and DDE in sediment. WATER SA-PRETORIA-. 1998 Jul 1;24:205-14.

13. Ananth V, Anand Gideon V and John Britto S. Anatomical and phytochemical investigation of embeliatsjeriam-cottam (roem. \&Schult.) A.Dc. International Journal of Pharmacy and Biological Sciences. 2018; 8(3):710-711

14. Nazneen F, Muddassir M, Meshram K, Umekar MJ, Lohiya RT. Phytochemical Screening and Comparative Anthelmintic Activity of Alchoholic Extracts of Some Herbal Plants. Journal of Pharmaceutical Sciences and Research. 2017 Jul 1;9(7):124.

15. World Health Organization. Quality control methods for medicinal plant materials. World Health Organization; 1998.

16. Jalalpure SS, Alagawadi KR, Mahajanshetty CS, Salahuddin M, Shah B. In vitro antihelmintic property of various seed oils. Iranian journal of pharmaceutical research. 2010 Nov 20(4):281.

17. Sudha Singh, PragyaShrivastava ,Comparative Anthelmintic Activity of Hydroalcoholic extracts of Embeliaribes (ERE) and Ziziphusxylopyrus (ZRE), Asian Journal of Pharmaceutical Education and Research, July-September 2016, Vol -5, Issue-3, 33-42.

18. Efrem N. Tessema, ReinhardNeubert, Serge A. T. Fobofou, Anthelmintic activityguided fractionation and GC-MS analysis of extracts from Embeliaschimperifruits,International journal of applied research in natural products,2018, Volume 11, Issue 1, 11-16. 